BBA 8259

\title{
STUDIES ON THE ESTIMATION OF DEOXYRIBONUCLEIC ACID AND RIBONUCLEIC ACID IN RAT BRAIN
}

\author{
RICHARD J. SANTEN AND BERNARD W. AGRANOFF
}

Mental Health Research Institute and Department of Biological Chemistry, University of Michigan, Ann Arbor, Mich. (U.S.A.)

(Received December 3rd, I962)

\section{SUMMARY}

A method for the estimation of DNA and RNA in rat brain is described. The principal modifications of preexisting methods involve initial lipid extraction with chloroformmethanol and continuous stirring during alkaline hydrolysis of RNA and acid extraction of DNA. Comparison of ultraviolet-absorptive methods, phosphate determination, and orcinol reaction for RNA, shows a greater degree of correspondence than has previously been reported for brain tissue. Also, a relatively high degree of reproducibility for each of the methods used is obtained with a two-wavelength ultraviolet method. In addition to chemical separation of DNA and RNA components suitable for isotopic studies, an intact lipid fraction is obtained without acid or heating steps.

Intracranial injection of $\left[{ }^{3} \mathrm{H}\right]$ thymidine into young rats resulted in incorporation of as much as $10 \%$ of the injected dose into DNA in $2 \mathrm{~h}$.

The DNA per cell nucleus obtained from brain homogenates was found to be $6.4 \cdot \mathrm{IO}^{-12} \mathrm{~g}$. On this basis, there are $5.5 \cdot 1 \mathrm{O}^{8}$ cells in the brain of a young adult rat.

\section{INTRODUCTION}

A special role for the nucleic acids in the physiological function of the nervous system has been suggested by various observations ${ }^{1-5}$. In the course of preliminary investigations on this role, we encountered many difficulties, several of which have been previously reported by others. The diphenylamine reaction of Dische may yield unreliable results for DNA in nervous, as well as other tissues?. Another source of error is the presence of degradation products of phosphoproteins, which interfere with nucleic acid assays in dog brain ${ }^{6}$. Fractions reported to contain inositol phospholipid which are not removed by the usual ethanol-ether extraction in the SCHMIDTThanNhauser procedure ${ }^{8}$ interfere with phosphorus determinations of RNA $^{6,8}$. FLECK AND MUNRO ${ }^{10}$ have recently examined the extent of previously reported 11,12 peptide contamination which interferes with ultraviolet spectrophotometry of RNA. Loss of RNA and DNA into the trichloroacetic acid-soluble fraction prepared by the method of SCHMIDT AND THANNHAUSER as well as into the ethanol-ether lipid fraction have been noted. Much variation has also been reported in the time of alkaline hydrolysis necessary for degradation of RNA into acid-soluble nucleotides ${ }^{10}$ and for the extraction of DNA from the nucleoprotein residue with hot perchloric acid ${ }^{\mathbf{1 3}}$. 
The procedure presented here for the isolation and estimation of nucleic acids in the nervous system involves, as an initial step, a more complete lipid extraction than ordinarily used, followed by extraction of remaining acid-soluble substances. The method effects chemical isolation of lipid, acid-soluble, RNA, and DNA fractions, permitting multiple analyses on the same sample of brain tissue. It removes most of the non-nucleotide phosphorus from the RNA fraction. Since a completely clear alkaline hydrolysate can be obtained, aliquots from this fraction may be used for other determinations, such as brain protein. Other methods do not yield a clear hydrolysate ${ }^{14}$.

Radioisotopic techniques were used to establish the effectiveness and completeness of the various fractionations.

\section{METHODS AND MATERIALS}

$\left[M e-{ }^{3} \mathrm{H}\right]$ Thymidine (New England Nuclear Corporation, Boston) had a specific activity of $5430 \mathrm{mC} / \mathrm{mmole}$ and contained I mC/ml. [8-14 C]ATP (Schwarz BioResearch, Inc., Mount Vernon, N.Y. (U.S.A.)) had a specific activity of $3.5 \mu \mathrm{C} / \mathrm{mg}$. Double vacuum distilled $70 \%$ perchloric acid was obtained from the Frederick Smith Company, Columbus, Ohio. ${ }^{14} \mathrm{C}$ was counted in a Nuclear Chicago Gas-Flow Counter and ${ }^{3} \mathrm{H}$ in a Packard Tri-Carb Liquid Scintillation Counter. A Vortex Jr. Mixer (Scientific Industries, New York) was used.for resuspension of residues. Salmon-sperm highly polymerized DNA, and yeast RNA were obtained from the California Corporation for Biochemical Research. The DNA contained $7.72 \%$ phosphorus by analysis. The DNA and RNA standards were prepared by dissolving a weighed amount of nucleic acid in I N NH $\mathrm{NH}_{4} \mathrm{OH}$ and then diluting to volume. After heating with hot I N perchloric acid for $30 \mathrm{~min}$, the DNA standard had an extinction coefficient of

$$
\varepsilon(\mathrm{P})=\frac{30.98 \times \text { absorbancy }}{\mathrm{g} \text { phosphorus } / \mathrm{l} \times \mathrm{cm} \text { light path }}
$$

of 9040 at $268.5 \mathrm{~m} \mu$. The RNA contained $7.88 \%$ phosphorus and had an $\varepsilon(\mathrm{P})$ of Io 500 at $260 \mathrm{~m} \mu$ after $\mathrm{I} 8 \mathrm{~h}$ of alkaline hydrolysis in I $\mathrm{N} \mathrm{KOH}$. Ultraviolet absorption was measured in a Beckman-DU Spectrophotometer. In addition a two-wavelength method11 was used to estimate both DNA and RNA.

Holtzman derived albino rats were obtained from Rawley Farms, Plymouth, Mich. (U.S.A.).

\section{Preparation of "tissue breakdown products"}

In order to correct for interfering ultraviolet-absorbing substances, a "tissue breakdown products" extract was prepared according to a modification of the method of TSANEv AND Markov"1 Lipid and trichloroacetic acid-soluble materials were extracted from a brain as described below under PROCEDURE. Two 30-min extractions with constant magnetic stirring at $80^{\circ}$ in $\mathrm{I} N$ perchloric acid removed the nucleic acids. The residue was washed with distilled water, ethanol, absolute ethanol, ether, and dried. Treatment according to PROCEDURE was then resumed with alkaline hydrolysis. The perchloric acid-soluble fraction minus the RNA, and the hot perchloric acid fraction minus the DNA were isolated. An absorption spectrum (Fig. I) was 
A

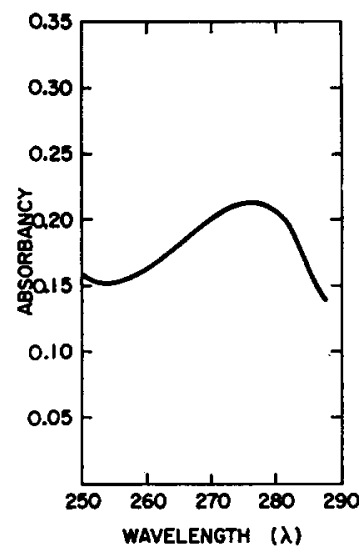

B

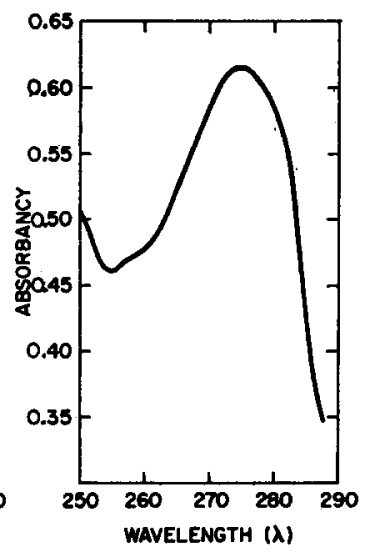

Fig. I. Absorption spectra ( $\lambda$ in $m \mu$ ) of tissue breakdown products. A represents the hot-perchloric acid-soluble fraction and $B$ the perchloric acid-soluble fraction. For details see text.

determined for each. From these data, a value of $\frac{A_{288}}{A_{280}}=0.90 \mathrm{I}$ for the ratio of the absorbancies of the "tissue breakdown products" of the perchloric acid-soluble fraction was obtained and of $\frac{A_{285}}{A_{288.5}}=0.842$ for the hot perchloric acid-treated fraction. The ratios of salmon-sperm DNA, $\frac{A_{285}}{A_{288.5}}=0.534$ after $30 \mathrm{~min}$ of heating in hot perchloric acid, and of yeast RNA, $\frac{A_{288}}{A_{260}}=0.423$ after the hyperchromic effects of $\mathrm{I} 8 \mathrm{~h}$ of alkaline hydrolysis, were determined. The absorbancy of RNA and DNA in tissue extracts at 260 and $268.5 \mathrm{~m} \mu$ can be calculated by the following equations.

RNA : x $=A_{260}$ of RNA; $\mathrm{y}=A_{280}$ of tissue breakdown products; observed $A_{260}=\mathrm{x}+\mathrm{y} ;$ observed $A_{286}=0.423 \mathrm{x}+0.90 \mathrm{y} ; \mathrm{x}=\frac{0.901 A_{280}-A_{286}}{0.47^{8}}$

DNA: $\mathrm{x}=A_{268.5}$ of DNA; $\mathrm{y}=A_{268.5}$ of tissue breakdown products; observed $A_{268.5}=\mathrm{x}+\mathrm{y} ;$ observed $A_{285}=0.534 \mathrm{x}+0.842 \mathrm{y} ; \mathrm{x}=\frac{0.842 A_{288.5}-A_{285}}{0.308}$ TSANEV AND MARKOV ${ }^{11}$ report that for most tissues $y=1.0$, thus simplifying the equations. These selected wavelengths were used in the present study despite the additional calculations when $\mathrm{y} \neq \mathrm{I} .0$, so that a more direct comparison to the published procedure could be made.

For determination of DNA and RNA per nucleus, the method of HELLER AND ELLIOT $^{15}$ was employed for the isolation and counting of nuclei. The nuclear residue was extracted twice with $5 \%$ trichloroacetic acid, washed with $95 \%$ ethanol, and the lipids were then extracted once with chloroform-methanol-water (38:19:3, v/v). After washing with $95 \%$ ethanol and ether, the residue was treated according to PROCEDURE for isolation and estimation of both RNA and DNA.

Ribose was determined with an orcinol method ${ }^{16}$. Yeast RNA was used as the standard.

Total phosphorus was measured by the method of $\mathrm{KING}^{17}$.

Inorganic phosphorus was estimated by a modification of the method of BERENBLUM AND Chain 18 . 


\section{PROCEDURE}

Male albino rats weighing from 90 to $200 \mathrm{~g}$ are removed from cages containing 5-8 rats and are rapidly decapitated. The olfactory lobes are dissected away from the brain, the brain stem severed $5 \mathrm{~mm}$ caudal to the cerebellum and the remaining brain removed intact. Individual brains are chilled, blotted on filter paper, and weighed. No longer than 55 min elapse between decapitation and homogenization. The brains, weighing I.5-2.0 g, are homogenized in $32 \mathrm{ml}$ of chloroform-methanol $(2: \mathrm{I}, \mathrm{v} / \mathrm{v})$ with a motorized Potter-Elvehjem homogenizer having a Teflon pestle. The homogenate is transferred to a $20 \times 2.5-\mathrm{cm}$ screw-cap test tube. The remaining contents of the homogenizer are rinsed into the test tube with $20 \mathrm{ml}$ of chloroform-methanol-water $(38: 19: 3, \mathrm{v} / \mathrm{v})$. A ro $\times 5 \mathrm{~mm}$ Teflon-coated stirring magnet is added to each tube to insure adequate extractions. All subsequent steps, including alkaline hydrolysis and hot and cold' perchloric acid extractions, are performed with magnetic stirring. The suspension is centrifuged at rooo $\times g$ for ro min and the supernatant fluid drawn off with a Pasteur pipette. The residue is extracted twice with Io $\mathrm{ml}$ portions of the chloroform-methanol-water. The supernatant solutions are combined and represent the lipid fraction. 'This fraction is backwashed with 0.2 vol. of water at this time when further studies are desired on either the lipid extract or the "acid-soluble" fractions. Traces of chloroform are removed from the residue by washing with $20 \mathrm{ml}$ of $95 \%$ ethanol to prevent formation of a gummy residue upon direct addition of trichloroacetic acid. The residue is extracted twice with $40 \mathrm{ml}$ of $5 \%$ ice-cold trichloroacetic acid and then with $20 \mathrm{ml}$ of cold $95 \%$ ethanol. The residue is then washed with $20 \mathrm{ml}$ of absolute ethanol, then with ether, and finally dried with a stream of nitrogen. Alkaline hydrolysis with $16 \mathrm{ml}$ of I N KOH is performed at $37^{\circ}$ for $2.5 \mathrm{~h}$. The clear hydrolysate is transferred to a volumetric flask and is difuted to $25 \mathrm{ml}$ with I N KOH. $3 \mathrm{ml}$ aliquots are transferred to $125 \times 15-\mathrm{mm}$ test tubes for duplicate RNA and DNA analyses. To the aliquots, cooled in ice, $0.3 \mathrm{ml}$ of $70 \%$ perchloric acid is added. 10 $\times 3-\mathrm{mm}$ Teflon-coated magnetic stirring bars are added and are used in all remaining extractions. Thorough resuspension of the residue by frequent mixing with the Vortex Mixer during a 20-min period insures complete precipitation of the DNA and protein. The residue is washed twice with a few $\mathrm{ml}$ of cold I $\mathrm{N}$ perchloric acid and the supernatant RNA extracts obtained by centrifugation are withdrawn, combined, and brought to a $25-\mathrm{ml}$ volume with I $\mathrm{N}$ perchloric acid. DNA is released from the residue by two successive extractions at $80^{\circ}$ with $\mathrm{I} N$ perchloric acid for $30 \mathrm{~min}$ and dilution to $25 \mathrm{ml}$ with I $\mathrm{N}$ perchloric acid.

The $25 \mathrm{ml}$ solutions of $\mathrm{RNA}^{*}$ and DNA, respectively, are read directly in the spectrophotometer against blanks consisting of a supernatant solution from the addition of I N KOH to I N perchloric acid for RNA and I N perchloric acid for DNA. Io-ml aliquots of each solution are ashed for each phosphate determination by carefully heating the perchloric acid extract to near dryness in a Kjeldahl flask, cooling, adding $2-3$ drops of $30 \% \mathrm{H}_{2} \mathrm{O}_{2}$ and repeating the procedure.

\section{RESULTS AND DISCUSSION}

Reports of nucleic acid content in rat brain differ more than can be attributed to age

* A precipitate of additional $\mathrm{KClO}_{4}$ which may form on cooling is removed by centrifugation. 
or strain variation. Schmidt AND Thannhauser ${ }^{8}$ reported $32.6 \mathrm{mg}$ RNA-P and I5.I mg DNA-P per IOo $\mathrm{g}$ wet wt. rat brain. SCHNEIDER AND KLUG ${ }^{19}$ found 9.6I5.3 mg RNA-P and ro.8-I9.7 mg DNA-P per roo $g$ wet wt. rat brain. If we assume $8 \% \mathrm{P}$ content, the study of DAHL and Samson ${ }^{20}$ indicates $12 \mathrm{mg}$ DNA-P per $100 \mathrm{~g}$ wet wt. rat brain. A similar calculation from the study of TALWAR et al. ${ }^{8}$ shows $8.5 \mathrm{mg}$ RNA-P per roo $\mathrm{g}$ wet wt. rat brain. Our initial studies employed the method of TSANEV AND MaRkov ${ }^{11}$. This procedure involves homogenization in cold trichloroacetic acid extraction with ethanol, then hot ethanol-ether, followed by methanolether. Alkaline hydrolysis is performed in I N KOH at $37^{\circ}$ for $\mathrm{I} 8 \mathrm{~h}$. DNA is extracted from the residue of the acidified hydrolysate with hot perchloric acid. The results of the application of this method to brain are shown in Table I. The high values for RNA-P based on actual $P$ determination are in keeping with the findings of LogAN et al. ${ }^{6}$, who applied the procedure of SCHMIDT AND THANNHAUSER ${ }^{8}$ to dog brain. While this high value has been attributed to brain inositide in the dog, it is of interest that there is apparently very little complex inositide in the rat brain ${ }^{21}$. As will be seen, however, more complete lipid extraction does result in some reduction of the RNA-P determination. When the results of Table I are compared to those found by

\section{TABLE I}

\section{NUCleIC ACID CONTENT OF RAT BRAIN BY PROCEDURE OF TSANEV AND Markov}

In groups $A$ and $B$ below, the brains were removed and homogenized with trichloroacetic acid within $15 \mathrm{~min}$ after decapitation. Brains from groups $\mathrm{C}$ and D were removed $4 \mathrm{~h}$ after the animals were sacrificed by $\mathrm{CO}_{2}$ inhalation. They were stored in $10 \%$ neutral formalin for one week, then analyzed. In group $\mathrm{E}$, the brains were frozen in liquid $\mathrm{N}_{2}$ immediately after the rats were decapitated and then stored for one week at $-15^{\circ}$. Each brain was homogenized in trichloroacetic acid and analyzed according to the procedure of TSANEV and MARKov. All values are expressed as $\mathrm{mg}$ phosphorus per $100 \mathrm{~g}$ wet wt. of tissue and are given as the mean and standard error of the mean.

\begin{tabular}{|c|c|c|c|c|c|c|c|c|c|c|}
\hline \multirow{2}{*}{$\begin{array}{l}\text { Group } \\
\text { (number } \\
\text { of } \\
\text { animals) }\end{array}$} & \multirow{2}{*}{$\begin{array}{l}\text { Animal } \\
\text { weight } \\
\text { (g) } \\
\text { (range) }\end{array}$} & \multirow{2}{*}{$\begin{array}{c}\text { Brain } \\
\text { weight } \\
\text { (g) }\end{array}$} & \multicolumn{4}{|c|}{ RNA } & \multicolumn{4}{|c|}{$D N A$} \\
\hline & & & $A_{360}$ & $\Delta A^{*}$ & Oxpinol & $P$ & $A_{\text {sem.8 }}$ & $\Delta \boldsymbol{A}^{*}$ & $\begin{array}{l}\text { Diphenyl- } \\
\text { amine }\end{array}$ & $P$ \\
\hline $\begin{array}{c}\text { A } \\
(4)\end{array}$ & $201-23^{8}$ & $\begin{array}{c}\mathrm{I} .83 \\
\pm \\
0.05\end{array}$ & $\begin{array}{l}23.8 \\
\pm \\
0.33\end{array}$ & $\begin{array}{c}\text { I5. } \\
\pm \\
0.5^{\circ}\end{array}$ & $\begin{array}{c}23.5 \\
\pm \\
0.18\end{array}$ & & $\begin{array}{l}12.4 \\
\pm \\
\text { I.7I }\end{array}$ & $\begin{array}{l}7.35 \\
\pm \\
0.34\end{array}$ & & \\
\hline $\begin{array}{c}B \\
(4)\end{array}$ & 106-116 & $\begin{array}{c}1.62 \\
\pm \\
0.04\end{array}$ & $\begin{array}{l}24.7 \\
\pm \\
0.81\end{array}$ & $\begin{array}{c}14.7 \\
\pm \\
0.38\end{array}$ & $\begin{array}{c}29.7 \\
\pm \\
2.57\end{array}$ & & $\begin{array}{l}\text { IO. I } \\
\pm \\
0.24\end{array}$ & $\begin{array}{l}8.08 \\
\pm \\
0.44\end{array}$ & $\begin{array}{c}16.9 \\
\pm \\
I .40\end{array}$ & $\begin{array}{l}7.7 \mathrm{I} \\
\pm \\
\mathrm{I.6I}\end{array}$ \\
\hline $\begin{array}{c}C \\
(4)\end{array}$ & I I 2-I 30 & $\begin{array}{c}1.67 \\
\pm \\
0.01\end{array}$ & $\begin{array}{c}26.2 \\
\pm \\
0.80\end{array}$ & $\begin{array}{c}18.6 \\
\pm \\
0.68\end{array}$ & $\begin{array}{c}27.4 \\
\pm \\
0.23\end{array}$ & $\begin{array}{c}45.3 \\
\pm \\
2.9\end{array}$ & $\begin{array}{l}9.53 \\
\pm \\
\text { I.I4 }\end{array}$ & $\begin{array}{l}7.01 \\
\pm \\
0.9 \mathrm{I}\end{array}$ & & $\begin{array}{l}11.7 \\
\pm \\
1.17\end{array}$ \\
\hline $\begin{array}{c}D \\
(4)\end{array}$ & $23^{8-262}$ & $\begin{array}{c}1.95 \\
\pm \\
0.08\end{array}$ & $\begin{array}{l}23.6 \\
\pm \\
1.35\end{array}$ & $\begin{array}{c}15.4 \\
\pm \\
3.20\end{array}$ & $\begin{array}{c}27.9 \\
\pm \\
3.3\end{array}$ & $\begin{array}{c}36.9 \\
\pm \\
9.5\end{array}$ & $\begin{array}{c}13.4 \\
\pm \\
1.92\end{array}$ & $\begin{array}{c}10.5 \\
\pm . \\
1.4\end{array}$ & $\begin{array}{c}17.0 \\
\pm \\
2.28\end{array}$ & $\begin{array}{c}14.9 \\
\pm \\
1.1\end{array}$ \\
\hline$\underset{(3)}{E}$ & $97^{-1} 30$ & $\begin{array}{c}1.51 \\
\pm \\
0.09\end{array}$ & $\begin{array}{c}24.5 \\
\pm \\
1.78\end{array}$ & $\begin{array}{c}15.5 \\
\pm \\
0.63\end{array}$ & $\begin{array}{c}25.5 \\
\pm \\
2.9\end{array}$ & $\begin{array}{c}42.3 \\
\pm \\
9.7\end{array}$ & $\begin{array}{l}13.0 \\
\pm \\
\mathbf{I . 2 8}\end{array}$ & $\begin{array}{c}\mathbf{I I . 0} \\
\pm \\
\mathrm{I} .2\end{array}$ & $\begin{array}{c}\text { I3.I } \\
\pm \\
\text { I.I }\end{array}$ & $\begin{array}{c}11.7 \\
\pm \\
2.4\end{array}$ \\
\hline
\end{tabular}

"Two-wavelength method. 
TSAnEv AND Markov in rat liver ${ }^{11}$, there are similarities. Application of the twowavelength method to rat brain results in RNA values which are $4 \mathrm{I} \%$ lower than that obtained by $A_{260}$, while DNA is reduced $20 \%$ from the value obtained by the $A_{268.5}$ method. In liver studies, the two-wavelength method yields values for RNA and DNA which are $44 \%$ and $28 \%$ lower respectively than the corresponding onewavelength methods ${ }^{11}$. Fair agreement between the $A_{260}$ and orcinol values are noted. In agreement with the report of MAY AND GRENELL ${ }^{14}$, the alkaline hydrolysate of brain was not clear even after $\mathrm{I} 8 \mathrm{~h}$ at $37^{\circ}$. The diphenylamine reaction produced a purple color with tissue extracts ${ }^{22}$ while a blue color was obtained with both deoxyribose and DNA standards. In addition, the color yield was variable. For these reasons, the diphenylamine reaction was not used in further studies. While improvements in the nucleic acid determination were pursued, it did seem from the results of Table I that the various methods of treatment of the brain prior to analysis gave sufficiently similar results to suggest that DNA and RNA are stable during preparation and storage.

Modifications included the use of a more complete lipid solvent, chloroformmethanol, at room temperature ${ }^{23}$. The use of hot chloroform-methanol prior to nucleic acid determination has been described for mouse brain ${ }^{24}$. If acid extraction is performed after the lipid extraction, a satisfactory extract for lipid determination can be obtained from the same brains used for nucleic acid analysis.

In order to confirm that the described new procedure afforded chemical separation of brain into the various fractions, radioisotopic tracers were used. Table II demonstrates the distribution of $\left[8{ }^{14} \mathrm{C}\right] \mathrm{ATP}$ added just prior to homogenization. Most of the material was present in the trichloroacetic acid supernatant solution, and to a lesser extent in the aqueous phase of the lipid backwash. However, the distribution of other acid-soluble materials between these two fractions must be variable.

$\left[\mathrm{Me}_{-}{ }^{3} \mathrm{H}\right]$ Thymidine was injected into albino rats in order to evaluate the chemical isolation of DNA. Several problems arose in carrying out this experiment. Previous reports have questioned the possibility of labeling brain DNA by intraperitoneal

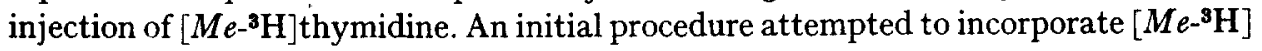

\section{TABLE II}

FRACTIONAL DISTRIBUTION OF [8-14C]ATP DURING PROCEDURE FOR BRAIN NUCLEIC ACIDS

A chilled rat brain was placed in the homogenizer along with $0.1 \mathrm{ml}$ [8-14C]ATP containing 202 ooo counts $/ \mathrm{min}$ and $32 \mathrm{ml}$ of chloroform-methanol $(2: \mathrm{r}, \mathrm{v} / \mathrm{v})$ were immediately added. Fractionation was performed as described in PROCEDURE and an aliquot of each fraction was counted. The chloroform-methanol-water fraction was backwashed with 0.2 vol. of $\mathrm{H}_{2} \mathrm{O}$ to obtain chloroform and methanol-water fractions, each of which was counted. $91 \%$ of the radioactivity was recovered.

\begin{tabular}{lr}
\hline \multicolumn{1}{c}{ Fraction } & $\begin{array}{r}\text { Radioactivity } \\
\text { (cousts/mix) }\end{array}$ \\
\hline Methanol-water backwash (upper layer) & I I 000 \\
Chloroform phase (lower layer) & 998 \\
Trichloroacetic acid supernatant & I 70 o0o \\
Alcohol washes & I 470 \\
Ether washes & 27 \\
KOH hydrolysate (DNA, RNA, protein) & 342 \\
\hline
\end{tabular}


TABLE III

RADIOACTIVITY IN FRACTIONS FOLLOWING INTRACRANIAL INJECTION OF [Me-8H]THYMIDINE

Unanesthetized new-born rats were injected with $\left[M e-{ }^{2} \mathrm{H}\right]$ thymidine (I $\left.\mu \mathrm{C} / \mu \mathrm{l}\right)$ using a $0.5-\mathrm{ml}$ syringe and a 27-gauge needle. Fractions were prepared as in PROCEDURE except for time of alkaline hydrolysis as noted below.

\begin{tabular}{|c|c|c|c|c|c|c|}
\hline Experiment & \multicolumn{2}{|c|}{ I } & \multicolumn{2}{|r|}{2} & \multicolumn{2}{|c|}{3} \\
\hline Amount injected $(\mu \mathrm{C})$ & \multicolumn{2}{|c|}{50} & \multicolumn{2}{|c|}{50} & \multicolumn{2}{|c|}{35} \\
\hline Age (days) & \multicolumn{2}{|c|}{2} & \multicolumn{2}{|r|}{2} & \multicolumn{2}{|c|}{7} \\
\hline $\begin{array}{l}\text { Time interval between } \\
\text { injection and sacrifice (h) }\end{array}$ & \multicolumn{2}{|c|}{5} & \multicolumn{2}{|c|}{20} & \multicolumn{2}{|c|}{2} \\
\hline Hours of KOH hydrolysis (h) & 2 & 5 & 2 & 5 & 13 & 18 \\
\hline RNA (counts/min) & 5100 & 5490 & 8720 & 8460 & 13200 & 12800 \\
\hline DNA (counts/min) & 262000 & 255000 & 200000 & 192000 & 550000 & 568000 \\
\hline $\begin{array}{l}\text { Protein (perchloric acid residue) } \\
\text { (counts } / \mathrm{min} \text { ) }\end{array}$ & $737^{\circ}$ & 2880 & 5500 & 3900 & 14500 & 7430 \\
\hline $\begin{array}{l}\text { Chloroform-methanol-water } \\
\text { (counts/min) }\end{array}$ & \multicolumn{2}{|c|}{ I 44000} & \multicolumn{2}{|c|}{68200} & \multicolumn{2}{|c|}{583 ooo } \\
\hline $\begin{array}{l}\text { Methanol-water backwash" } \\
\text { (counts/min) }\end{array}$ & \multicolumn{2}{|c|}{ I 29000} & \multicolumn{2}{|c|}{55000} & \multicolumn{2}{|c|}{544 100 } \\
\hline Chloroform (counts/min) & \multicolumn{2}{|c|}{15000} & \multicolumn{2}{|c|}{13000} & \multicolumn{2}{|c|}{$3^{8} 900$} \\
\hline $\begin{array}{l}\text { Methanol-water fraction, } \\
\text { dialyzable (counts } / \mathrm{min})^{* *}\end{array}$ & & & & & \multicolumn{2}{|c|}{522000} \\
\hline $\begin{array}{l}\text { Methanol-water fraction, } \\
\text { non-dialyzable (counts/min) ** }\end{array}$ & & & & & \multicolumn{2}{|c|}{12300} \\
\hline $\begin{array}{l}\text { Trichloroacetic acid extract } \\
\text { (counts/min) }\end{array}$ & \multicolumn{2}{|c|}{2 IOI } & \multicolumn{2}{|c|}{$767^{\circ}$} & \multicolumn{2}{|c|}{$5^{8} 5^{00}$} \\
\hline Dialyzable (counts/min) ** & & & & & \multicolumn{2}{|c|}{$56900^{*}$} \\
\hline Non-dialyzable (counts/min) ${ }^{\star \star}$ & & & & & \multicolumn{2}{|c|}{ I 600} \\
\hline Alcohol (counts/min) & & & & & \multicolumn{2}{|c|}{20000} \\
\hline Ether (counts/min) & & & & & \multicolumn{2}{|c|}{140} \\
\hline
\end{tabular}

* Calculated by difference.

** After correction for dialyzable material in sac at equilibrium.

thymidine into brain DNA by introducing $200 \mu \mathrm{C}$ into the peritoneal cavity of a 45-g rat. Seven days after injection the rat was sacrificed. Extensive incorporation of the tritium into protein, RNA, and DNA resulted. In subsequent experiments, $\left[M e^{-}{ }^{3} \mathrm{H}\right]-$ thymidine was injected into rat brain ${ }^{25}$. The perchloric acid and trichloroacetic acid extracts were counted with a water-miscible counting system (cellosolve- 
dioxane-xylene $(3: 3: I, v / v)$, containing I $\%$ 2,5-diphenyloxazole, $0.05 \% p$-bis 2 (phenyloxazolyl)]-benzene, and $5 \%$ naphthalene ${ }^{26}$ ). Up to $\mathrm{I} \mathrm{ml}$ of aqueous solution could be counted with efficiencies ranging from $2.4 \%$ to $8.5 \%$. For the chloroformmethanol-water lipid extract and also for protein residues, $2 \mathrm{ml}$ of hyamine hydroxide in $15 \mathrm{ml}$ of toluene, containing $0.4 \% 2,5$-diphenyloxazole and o.or $\% p$-bis [2-(phenyloxazolyl)]-benzene, was employed.

The duration of alkaline hydrolysis and of hot perchloric acid extractions of brains from rats injected with $\left[{ }^{3} \mathrm{H}\right]$ thymidine was varied to study effects on the chemical isolation of DNA and RNA. Table III demonstrates the effectiveness of isolation and the stability of DNA throughout the I8-h alkaline hydrolysis. The observed slight incorporation of counts into all fractions might be explained by metabolic interconversion of thymidine to other metabolites. Varying the time of the $80^{\circ}$ perchloric acid extraction of DNA demonstrated that 20 min is sufficient to render $95 \%$ of DNA soluble from the nucleoprotein precipitate as shown by Fig. 2.

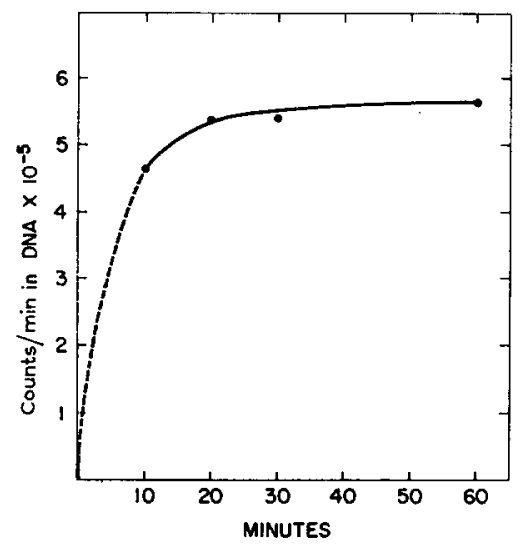

Fig. 2. DNA from a 5 -day-old rat, sacrificed $2 \mathrm{~h}$ after injection of $\left[M e^{-3} \mathrm{H}\right]$ thymidine (Table III), was extracted from an $\mathrm{I} 8 \mathrm{-h}$ alkaline hydrolysate with I $\mathrm{N}$ perchloric acid at $80^{\circ}$ for times indicated.

As seen in Table III, the greater number of counts in the chloroform-methanolwater fractions are dialyzable and therefore not DNA. The counts are more soluble in methanol-water than in chloroform and 270 ooo out of 540 ooo counts $/$ min stick to charcoal. It appears probable that the counts represent thymidine, thymidylic acid, or other metabolites. Counts present as ${ }^{3} \mathrm{HOH}$ would be expected to be lost during drying of aqueous samples prior to counting.

Since the ages of the rats, the amount of radioactivity injected intracranially, as well as the exact site of injection in the brain varied, the amounts incorporated into DNA are not directly comparable. It is impressive, however, that $2 \mathrm{~h}$ after a single intracranial injection, Io \% of the thymidine is incorporated into DNA. Whether or not the labeling of DNA is localized to a region around the injection site or is uniformly distributed throughout the brain is unknown.

Whole rat brain determinations as described in PROCEDURE with varying lengths of time of alkaline hydrolysis produced results with a high degree of reproducibility, particularly with the ultraviolet methods, as shown in Tables IV and V. 


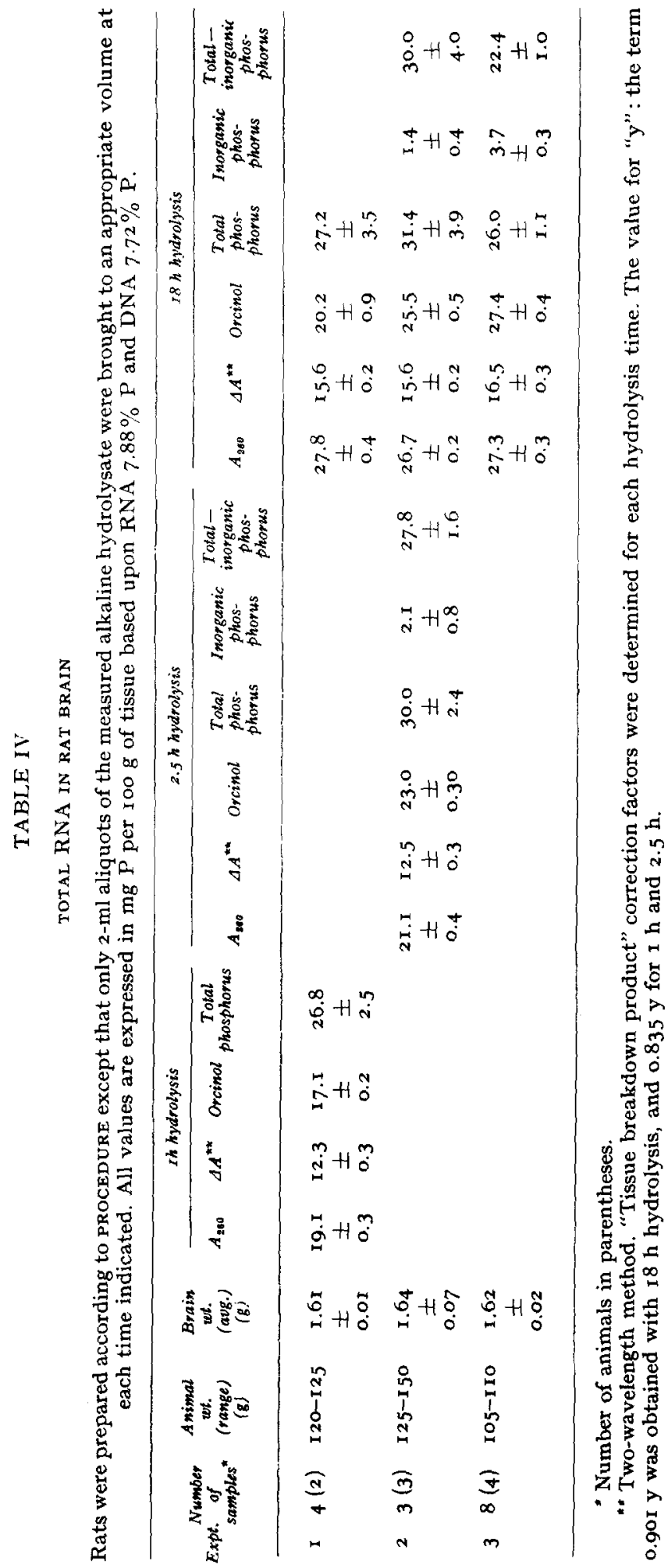


In the present procedure, there is again fair correspondence between the $A_{260}$ and the orcinol-derived values. The $\mathrm{I} 8 \mathrm{-h}$ values are similar to those obtained in brain analyzed by the procedure of TSANEV AND MARkov (Table I) except that the $P$ values are much lower. It is not apparent that the extraction of RNA is complete even after $\mathrm{I} 8 \mathrm{~h}$ of hydrolysis. Orcinol determinations on the whole alkaline hydrolysate show a net increase in orcinol-reacting material over the $\mathrm{I} 8$-h period, suggesting that non-nucleotide materials are slowly producing chromogenic contaminants. In studies with liver tissue, FLECK AND MUNRo ${ }^{10}$ find no additional orcinol-reacting

TABLE V

TOTAL DNA IN RAT BRAIN

For details see Table IV.

\begin{tabular}{|c|c|c|c|c|c|c|c|c|c|}
\hline \multirow{2}{*}{ Expt." } & \multicolumn{3}{|c|}{ I h hydrolysis } & \multicolumn{3}{|c|}{2.5 h hydrolysis } & \multicolumn{3}{|c|}{ I 8 h hydrolysis } \\
\hline & $A_{208.8}$ & $\Delta A^{* *}$ & $P$ & $A_{30 \mathrm{~s}}$ & $\Delta A^{\text {k* }}$ & $P$ & $A_{268.5}$ & $\Delta A^{* *}$ & $P$ \\
\hline $\mathbf{I}$ & $\begin{array}{c}23.1 \\
\pm \\
0.5\end{array}$ & $\begin{array}{c}\text { I } 8.0 \\
\pm \\
0.6\end{array}$ & $\begin{array}{c}\text { I6.9 } \\
\pm \\
0.7\end{array}$ & & & & $\begin{array}{c}\text { I9.9 } \\
\pm \\
0.8\end{array}$ & $\begin{array}{c}17.3 \\
\pm \\
0.6\end{array}$ & $\begin{array}{c}13.8 \\
\pm \\
0.3\end{array}$ \\
\hline 2 & & & & $\begin{array}{c}22.3 \\
\pm \\
0.4\end{array}$ & $\begin{array}{c}17.7 \\
\pm \\
0.6\end{array}$ & $\begin{array}{l}\text { I6. I } \\
\pm \\
\text { I.7 }\end{array}$ & $\begin{array}{c}\text { I9.4 } \\
\pm \\
0.2\end{array}$ & $\begin{array}{c}\mathbf{1} 6.7 \\
\pm \\
0.6\end{array}$ & $\begin{array}{c}\text { I } 5 . \mathrm{r} \\
\pm \\
0.5\end{array}$ \\
\hline 3 & & & & & & & $\begin{array}{c}\text { I9.5 } \\
\pm \\
0.5\end{array}$ & $\begin{array}{c}17 \cdot 3 \\
\pm \\
1.0\end{array}$ & $\begin{array}{c}16.0 \\
\pm \\
0.9\end{array}$ \\
\hline
\end{tabular}

- These experiment numbers refer to Table IV. Identical numbers of samples to those given in Table IV were used for DNA determination.

"* Two-wavelength method.

material released after I $h$ of hydrolysis, even if the lipid is not previously extracted. The increase in orcinol-reacting material in the present study appears to be due then to materials not found in liver.

The various procedures yield values for RNA in rat brain which are quite reproducible, but with considerable variance from method to method. Objections to the use of $A_{\mathbf{2 6 0}}$ (see ref. II) as well as two-wavelength procedures have been raised ${ }^{10}$. For the original purpose of this study, a method to establish variation in total brain DNA and RNA under different physiological conditions, one of the several methods of Table IV might be arbitrarily employed. In order to select the one most likely to be the correct value, I8-h hydrolysates were sorbed and eluted from Dowex-2-Cl (see ref. 27) and compared with RNA standard treated identically. This procedure is reported to remove non-nucleotide chromogens. The calculated RNA based on $A_{260}$ after Dowex corresponded to the value using $A_{\mathbf{2 6 0}}$ after $2.5 \mathrm{~h}$ hydrolysis by our procedure. The increase in orcinol-reacting and ultraviolet-absorbing material between 2.5 and $\mathrm{I} 8 \mathrm{~h}$ of hydrolysis appears to be non-nucleotide in nature. 
A more precise value for rat brain RNA awaits comparison with other isolation techniques.

The RNA-P is much lower in the present procedure, presumably due to more complete lipid extraction. However the $\mathrm{P}$ value is still high, and only a small fraction can be accounted for as inorganic $P$.

The DNA values obtained in Table $\mathrm{V}$ are considerably higher than those obtained in Table $I$ as well as by other methods ${ }^{6,28}$. This is undoubtedly due to the use of magnetic stirring during the hot perchloric acid extraction. That the additional material obtained is indeed DNA is supported by the fact that there is a closer correspondence between the $A_{\mathbf{2 6 8 . 5}}$ and $\Delta A$, an index of purity of the DNA. The DNA obtained from nuclei by the present method agrees well with previous estimates of rat nuclear $\mathrm{DNA}^{29}$. The DNA-P is somewhat low as has been noted in liver ${ }^{11}$. It appears then that the most satisfactory methods for brain RNA by the present procedure are the $A_{260}$ and orcinol after $2.5 \mathrm{~h}$ of hydrolysis for RNA, and the $\triangle A$ and $\mathrm{P}$ determination for DNA.

\section{DNA per nucleus}

Cell counts and nucleic acid determination were performed as described in METHODS AND MATERIALS on 2 young adult male rats. A total of 28 cell counts and 7 nucleic acid determinations were made on 400-mg sections of brain. Comparison of the absorbancy of the DNA fraction at 268.5 and $285 \mathrm{~m} \mu$ with the salmon-sperm DNA indicated the virtual absence of contaminating "tissue breakdown products". Therefore a single-wavelength method was used for DNA as well as for RNA.

The total DNA per nucleus was found to be $6.39 \pm 0.48 \cdot 10^{-12} \mathrm{~g}$.

The total RNA per nucleus was found to be $3.24 \pm 0.97 \cdot 10^{-12} \mathrm{~g}$. This is a maximum value and undoubtedly varies with cell type, and probably varies with brain area and completeness of separation of the nuclei from other cell constituents. Heller and ElliotT ${ }^{15}$ have reported $6.5 \cdot \mathrm{IO}^{-12} \mathrm{~g}$ DNA per dog brain cell, and 7.I $\cdot 10^{-12} \mathrm{~g}$ DNA per cat brain cell. THOMPSON et al.$^{29}$ report $6.7-7.2 \cdot 10^{-12} \mathrm{~g} \mathrm{DNA}$ per cell of various rat organs, although brain was not reported. Using a value of $17.1 \mathrm{mg}$ DNA-P/IOo $\mathrm{g}$ brain, a brain weight of $1.62 \mathrm{~g}$ and a $\mathrm{P}$ content of DNA of $7.72 \%$, we obtain a value of $5.5 \cdot \mathrm{IO}^{8}$ as the total number of cells in the rat brain. A considerably lower value of $2.3 \cdot 10^{8}$ cells per brain has been reported by direct counting methods $\mathrm{s}^{30}$.

\section{ACKNOWLEDGEMENTS}

This work was supported by grants from the Michigan Memorial Phoenix Project and from the National Institutes of Health (B3Ior), and supported in part by a student fellowship, American Cancer Society, I962, to R.J.S.

\section{REFERENCES}

1 R. W. Gerard, in Handbook of Physiology-Neurophysiology III, Am. Physiol. Soc., 196o, p. 1935. E. L. Noach, J. Joosting Bunk and A. Wijling, Acta Physiol, Pharmacol. Neerl., i I (1962) 54.

3 G. P. Talwar, B. Sadasivudu and V. S. Chitre, Nature, igt (I96I) Ioo7.

A. V. Palladin and G. E. Vladimirov, International Conference on the Peaceful Uses of Atomic Euergy, Vol. I 2, United Nations, New York, I956, p. 402. 
5 H. Hydén, in F. O. Schmitт, Macromolecular Specificity and Biological Memory, Mass. Inst. Tech. Press, Cambridge (Mass.), 1962, p. 55.

B J. E. Logan, W. A. Mannell and R. J. Rossiter, Biochem. J, 5 I (1952) 470.

7 S. Lovtruf and K. Roos, Biochim. Biophys. Acta, 53 (I96I) I.

8 G. Schmidt and S. J. Thannhauser, J. Biol. Chem., I6I (I945) 83.

- G. Schmidt, in S. P. Colowick and N. O. Kaplan, Methods in Enzymology, Vol. 3, Academic Press, New York, 1947, p. 675 .

10 A. Fleck and H. N. Munro, Biochim. Biophys. Acta, 55 (I962) 57 I.

11 R. Tsanev and G. G. Markov, Biochim. Biophys. Acta, 42 (1960) 442.

12 E. Volkin AND W. E. Cohn, in D. Glick, Methods of Biochemical Analysis, Vol. I, Interscience Publishers, New York, 1952, p. 292.

13 W. C. Hutchison, E. D. Downie and H. N. Munro, Biochim. Biophys. Acta, 55 (1962) 561.

14 L. May and G. Grenell, Proc. Soc. Exptl. Biol. Med., 102 (1959) 235.

15 I. H. Heller and K. A. C. Elliot, Can. J. Biochem. Physiol., 32 (I954) 584.

16 W. C. Schneider, in S. P. Colowick and N. O. KAPLAN, Methods in Enzymology, Vol. 3. Academic Press, New York, 1947, p. 680.

17 E. J. KING, Biochem. J., 26 (I932) 292.

18 O. Lindberg and L. Ernster, in D. Glick. Methods of Biochemical Analysis, Vol. 3, Interscience Publishers, New York, I952, p. 7.

19 W. C. Schneider and H. L. KLUG, Cancer Research, 6 (I946) 69 I.

20 D. R. Dahl and F. E. Samson, Jr., Am. J. Physiol., ig6 (I959) 470.

21 H. Wagner, Ä. Lissau, J. Hölzl and L. Hörhammer, J. Lipid Res., 3 (1962) 177.

22 T. F. Slater, Nature, I89 (I96I) 834 .

23 J. Folch, I. Ascoli, M. Lees, J. A. Meath and F. N. LeBaron, J. Biol. Chem., i91 (I95I) 833.

24 L. L. Uzman and M. K. Rumley, $J$. Neurochem., 3 (r958) i 70.

25 L. Altman, Science, 135 (1962) I 127.

26 G. A. Bruno and J. E. Christian, Anal. Chem., 33 (1961) I 216.

27 M. DeDeken-Grenson and R. H. DeDeken, Biochim. Biophys. Acta, 31 (1959) 195.

28 J. M. Kissane and E. Robins, J. Biol. Chem., 233 (1958) I84.

29 R. Y. Thompson, F. C. Heagy, W. C. Hutchison and J. N. Davidson, Biochem. J., 53 (I953) 460 .

so J. I. NURNBERGER AND M. W. GORDON, in H. WAELSCH, Ultrastructure and Cellular Chemistry of Neural Tissue, Hoeber, New York, 1957, p. Ioo.

Biochim. Biophys. Acta, 72 (1963) 251-262 